\title{
Effect of Various Treatments on White Spot Syndrome Virus (WSSV) from Penaeus japonicus (Japan) and P. monodon (Thailand)
}

\author{
Minoru Maeda*1, Jiraporn Kasornchandra*2, Toshiaki Itami*1, Nobutaka Suzuki*3, \\ Oscar Hennig*4, Masakazu Kondo*1 Juan D. Albaladejo*5 \\ and Yukinori Takahashi*1 \\ *1Department of Applied Aquabiology, National Fisheries University, \\ Shimonoseki, Yamaguchi 759-6595, Japan \\ *2National Institute of Coastal Aquaculture, Songkla 90000, Thailand \\ *3 Department of Food Science and Technology, National Fisheries University, \\ Shimonoseki, Yamaguchi 759-6595, Japan \\ ${ }^{* 4}$ Faculty of Fisheries, Nagasaki University, Nagasaki 852-8131, Japan \\ *5 Bureau of Fisheries and Aquatic Resources, Department of Agriculture, \\ Quezon, Metro Manila 3008, Philippines
}

(Received February 27, 1998)

\begin{abstract}
Two causative agents of white spot syndrome (WSS), penaeid rod-shaped DNA virus (PRDV) from infected kuruma shrimp (Penaeus japonicus) in Japan and systemic ectodermal and mesodermal baculovirus (SEMBV) from black tiger shrimp ( $P$. monodon) in Thailand, were tested for their sensitivities to chemicals, temperature, drying and singlet oxygen $\left({ }^{1} \mathrm{O}_{2}\right)$. The infectivity of the treated PRDV and SEMBV was determined by challenge tests in kuruma shrimp and black tiger shrimp, respectively. Sodium hypochlorite inactivated PRDV at $1 \mathrm{ppm}$ for $30 \mathrm{~min}$ and at $5 \mathrm{ppm}$ for $10 \mathrm{~min}$. SEMBV was inactivated by sodium hypochlorite at $10 \mathrm{ppm}$ for $30 \mathrm{~min}$. Povidone-iodine inactivated these viruses at a concentration of $10 \mathrm{ppm}$ for $30 \mathrm{~min}$. A high concentration of $\mathrm{NaCl}$ (12.5\%) inactivated PRDV in $24 \mathrm{~h}$ at $25^{\circ} \mathrm{C}$, and $15 \% \mathrm{NaCl}$ inactivated SEMBV in $24 \mathrm{~h}$ at $28^{\circ} \mathrm{C}$. PRDV was inactivated by heating at $50^{\circ} \mathrm{C}$ for $20 \mathrm{~min}$, by drying at $30^{\circ} \mathrm{C}$, and by using ethyl ether. PRDV in the sea water maintained its infectivity for at least 120 days at $4^{\circ} \mathrm{C}$, and for more than 60 days but less than 120 days when kept at $25^{\circ} \mathrm{C}$. However, PRDV, when suspended in sea water at a lower concentration, maintained infectivity for 10 days at $4^{\circ} \mathrm{C}$ and for 7 days at $25^{\circ} \mathrm{C}$. SEMBV maintained infectivity in sea water for 5 days at $28^{\circ} \mathrm{C}$. PRDV was exposed to ${ }^{1} \mathrm{O}_{2}$, which was generated by an insoluble dye (rose bengal) and visible light. Shrimp that received ${ }^{1} \mathrm{O}_{2}$-exposed virus showed lower mortality than control shrimp, indicating that ${ }^{1} \mathrm{O}_{2}$ inactivated PRDV. This ${ }^{1} \mathrm{O}_{2}$ generating system is a simple, safe and effective technique that can be applied to aquaculture.
\end{abstract}

Key words: PRDV, SEMBV, WSSV, disinfectant, singlet oxygen, Penaeus japonicus, Penaeus monodon

Penaeid acute viremia (PAV) caused by penaeid rod-shaped DNA virus (PRDV) was first observed in the early spring of 1993 in cultured kuruma shrimp Penaeus japonicus in Japan (Inouye et al., 1994, 1996; Takahashi et al., 1994). This infection causes serious mortality accompanied by symptoms of white spots on the inside of the carapace, and reddish discoloration of the body. Similar virus infections were found in black tiger shrimp P. monodon in Thailand, where the

Address for Correspondence: Dr. Toshiaki Itami, 2-7-1, NagataHonmachi, Shimonoseki, Yamaguchi 759-6595, Japan

Fax :+81-832-86-7435

E-mail: itamit@fish-u.ac.jp causative agent of this infection was named systemic ectodermal and mesodermal baculovirus (SEMBV) (Wongteerasupaya et al., 1995). PRDV (formerly named RV-PJ) was demonstrated to be closely related to SEMBV because both viruses could be detected by PCR using the DNA primers developed from PRDV (Takahashi et al., 1996) and the sequences of the PCR products were identical for both viruses (unpublished data). So far, closely related viruses have been described in the literature under various names including hypodermal and hematopoietic necrosis virus (Huang et al., 1995) and white spot baculovirus (Chou et al., 1995; Wang et al., 1995). These are now classified as 
unassigned viruses, but were previously classified in the Nudibaculovirinae, a subfamily of the Baculoviridae (Murphy et al., 1995). It has been proposed that this group of closely related viruses be called the white spot syndrome virus (WSSV) group (Nunan and Lightner, 1997). WSSV has been reported to infect many penaeid species and other arthropods (Lo et al., 1996; Maeda et al., 1997; Momoyama et al., 1997; Wang et al., 1997; Kasornchandra et al., 1998). In this article, we will refer to the WSSV group viruses in Japan and Thailand as PRDV and SEMBV, respectively. Information on the biological characteristics of the WSSV group is important for prevention and treatment. Accordingly, the present study was undertaken to develop effective countermeasures for controlling PRDV and SEMBV in penaeid shrimp culture.

\section{Materials and Methods}

\section{Viral preparation}

PRDV-infected shrimp, weighing an average of $12 \mathrm{~g}$, were obtained from a farm located in Yamaguchi Prefecture, Japan, and SEMBV-infected shrimp, weighing an average of $26 \mathrm{~g}$, were collected from a farm located in Songkla, Thailand. Lymphoid organs of 3 infected shrimp were collected, homogenized in $3 \mathrm{~m} l$ sterilized sea water and centrifuged at $10,000 \times g$ for $10 \mathrm{~min}$ at $4^{\circ} \mathrm{C}$. The supernatant was filtered through a $0.45 \mu \mathrm{m}$ membrane filter and the filtrate was used as the viral preparation (VP) stock for the experiments. VP stock was prepared individually for each experiment.

\section{Virucidal effect of sodium hypochlorite and povidone- iodine}

VP stock $(0.1 \mathrm{~m} l)$ was added to $50 \mathrm{~m} l$ sterilized sea water followed by addition of sodium hypochlorite and povidone-iodine to achieve final concentrations of active ingredients at $0,1,5,10,25$ and $50 \mathrm{ppm}$ for sodium hypochlorite, and at $0,1,5,10,20,50$ and $100 \mathrm{ppm}$ for povidone-iodine. The preparations were incubated at $25^{\circ} \mathrm{C}$ for $10 \mathrm{~min}$ or $30 \mathrm{~min}$ for PRDV, and at $28^{\circ} \mathrm{C}$ for $30 \mathrm{~min}$ for SEMBV. The preparations were then neutralized with $\mathrm{N} / 100$ or $\mathrm{N} / 1000$ sodium thiosulfate and injected into shrimp ( $P$. japonicus for PRDV and $P$. monodon for SEMBV) for challenge trials.

\section{Inactivation by heat treatment}

VP stock $(0.1 \mathrm{~m} l)$ was added to $10 \mathrm{~m} l$ sterile sea water which was previously filtered through a $0.20 \mu \mathrm{m}$ membrane and the preparations were heated at $25,40,50,60$,
70 or $80^{\circ} \mathrm{C}$ for $20 \mathrm{~min}$, and then the cooled samples were used for the challenge trials. Only PRDV was used in this experiment.

\section{Inactivation by drying}

VP stock $(0.1 \mathrm{~m} l)$ was absorbed to sterile filter paper (Toyo No. 2, Toyo Roshi Kaisha, Ltd, Japan). The filter paper was then incubated at $30^{\circ} \mathrm{C}$ for $0,0.5,1.0$, 1.5 and $2.0 \mathrm{~h}$, before being cut into small pieces and immersed in $50 \mathrm{~m} l$ sterile sea water with stirring for 10 $\mathrm{min}$. The paper suspensions were subsequently centrifuged and the supernatant was used for the challenge tests. As a control, VP stock $(1 \mathrm{~m} l)$ in a stoppered test tube was incubated at $30^{\circ} \mathrm{C}$ for $\mathrm{h}$. Immediately after $0.1 \mathrm{~m} l$ of this solution was absorbed to sterile filter paper, the paper was cut into small pieces and the supernatant for challenge tests was prepared in the same procedure mentioned above. Only PRDV was used in this experiment.

\section{Tolerance to ethyl ether}

VP stock $(4.0 \mathrm{~m} l)$ was added to $1.0 \mathrm{~m} l$ ethyl ether and incubated at $4^{\circ} \mathrm{C}$ for $18 \mathrm{~h}$. Sterile sea water was used to replace ethyl ether for the control. After incubation, reaction mixtures were stirred sufficiently to remove ethyl ether and were used for the challenge tests. Only PRDV was used in this experiment.

\section{Tolerance to $\mathrm{NaCl}$}

VP stock $(0.1 \mathrm{~m} l)$ was added to $50 \mathrm{~m} l$ of distilled water containing $\mathrm{NaCl}$ at concentrations ranging from 0.03 to $25.0 \%$. The mixtures were incubated at $25^{\circ} \mathrm{C}$ for $24 \mathrm{~h}$. Each solution was subsequently diluted $1: 10$ with sterile sea water before being used for the challenge tests.

\section{Duration of infectivity in sea water}

VP stock $(1.0 \mathrm{~m} l)$ of PRDV was placed in sterile test tubes and maintained at $4^{\circ} \mathrm{C}$ or $25^{\circ} \mathrm{C}$. The tube contents were sampled periodically for use in challenge tests. Diluted VP stock $\left(10^{-7}\right)$ was treated in the same way and also sampled periodically for use in challenge tests.

\section{Inactivation by singlet oxygen $\left({ }^{1} \mathrm{O}_{2}\right)$}

VP stock $(1.0 \mathrm{ml})$ of PRDV was mixed with $4 \mathrm{mg}$ of rose bengal (an insoluble, immobilized dye) and aerated for $10 \mathrm{~min}$ as a pretreatment. The mixture was then exposed to visible light for $20 \mathrm{~min}$ with aeration. By this irradiation, ${ }^{1} \mathrm{O}_{2}$, a molecular species of active oxy- 
gen with killing activity against microorganisms, was generated from the dye. As a control to examine the toxicity of ${ }^{1} \mathrm{O}_{2}$ and trace dye dissolved in sea water, a suspension of the dye without the virus was exposed to light. These samples were then used for challenge tests and the results were analyzed by $\chi^{2}$ tests. Only PRDV was used in this experiment.

\section{Challenge tests with treated virus solutions}

The shrimp used in this study were obtained from a shrimp culture farms where PAV or SEMBV was not endemic. The average body weights of kuruma shrimp and black tiger shrimp were $9 \mathrm{~g}$ and $30 \mathrm{~g}$, respectively. Treated viral preparations and control solutions were injected into the muscle of the third abdominal segment at a dose of $1 \%(\mathrm{v} / \mathrm{w})$ of shrimp body weight. The injected kuruma shrimp were subsequently kept in aquaria at $21-23^{\circ} \mathrm{C}$ and black tiger shrimp were kept at $28-30^{\circ} \mathrm{C}$. Mortality was monitored every day for 10 days after injection. Both species were fed commercial diets. The experiments on kuruma shrimp and black tiger shrimp were carried out in Japan and Thailand, respectively.

\section{Results and Discussion}

PAV is the second virus infection to cause serious economic loss in Japan. The first virus infection was baculoviral mid-gut gland necrosis (BMNV) (Sano et al., 1981), which affected mysis and post-larvae of kuruma shrimp (Momoyama et al., 1988). On the other hand, there are many viruses that cause economic losses in Thailand, such as hepatopancreatic parvo-like virus (HPV), monodon baculovirus (MBV), yellow head virus (YHV), infectious hypodermal and hematopoietic necrosis virus (IHHNV), and WSSV (Flegel, 1997). However, only limited information is available on the biological characteristics of these viruses.

The effects of various disinfectants and treatments on BMNV were investigated in detail by Momoyama (1989a, b, c, d). He determined the effects of these disinfectants by observation of the typical disease sign developed in kuruma shrimp challenged with the treated virus. In the present study, the effects were examined based on the difference in mortality rates of shrimp between treated-virus-injected group and control. Generally, injection of the PRDV or SEMBV can result in nearly $100 \%$ mortality within 4-6 days because of their high pathogenicity. We, therefore, used survival rate of challenged shrimp to evaluate the efficacy of the treatments.

Due to the lack of the cell lines to grow PRDV and SEMBV, it is not possible to measure viral concentrations and to standardize the initial preparations of VP stock. Hence, a comparison between these viruses in sensitivity to various treatments is not appropriate in this experiment.

\section{Virucidal effects of sodium hypochlorite and povidone- iodine}

PRDV was inactivated by a $10-\mathrm{min}$ exposure to $5 \mathrm{ppm}$ sodium hypochlorite, and by a 30-min exposure to $1 \mathrm{ppm}$ sodium hypochlorite. SEMBV was inactivated by a 30-min exposure to $10 \mathrm{ppm}$ sodium hypochlorite (Table 1). A 30-min exposure to $10 \mathrm{ppm}$ povidone-iodine inactivated PRDV and SEMBV (Table 2).

\section{Inactivation by heat treatment}

PRDV lost its infectivity by being heated at $50^{\circ} \mathrm{C}$ or higher for $20 \mathrm{~min}$ in sterile sea water (Table 3 ).

\section{Inactivation by drying}

The water content of the filter paper that had absorbed the virus suspension decreased from $86.2 \%$ to $3.4 \%$ within 30 min during drying treatment at $30^{\circ} \mathrm{C}$ (Table 4). The virus absorbed in the filter paper was inactivated within $1 \mathrm{~h}$ at $30^{\circ} \mathrm{C}$ but not in $30 \mathrm{~min}$, although the water content in both filter papers was the same. The control, in which the virus was kept in sterile sea water at $30^{\circ} \mathrm{C}$ for $1 \mathrm{~h}$, showed high pathogenicity.

Table 1. Virucidal effects of sodium hypochlolorite on PRDV and SEMBV

\begin{tabular}{|c|c|c|c|}
\hline \multirow{3}{*}{$\begin{array}{c}\text { Concentration } \\
(\mathrm{ppm})\end{array}$} & \multicolumn{3}{|c|}{ Number of shrimp dead } \\
\hline & \multicolumn{2}{|c|}{ PRDV* } & \multirow{2}{*}{$\frac{\mathrm{SEMBV}^{* *}}{30 \mathrm{~min}}$} \\
\hline & $10 \mathrm{~min}$ & $30 \mathrm{~min}$ & \\
\hline 50 & 0 & 0 & 0 \\
\hline 25 & 0 & NT & 0 \\
\hline 10 & 0 & 0 & 0 \\
\hline 5 & 0 & 0 & 1 \\
\hline 1 & NT & 0 & 4 \\
\hline 0 & 8 & 8 & 10 \\
\hline
\end{tabular}

* The temperature during the treatment was $25^{\circ} \mathrm{C}$. PRDV was injected into 10 kuruma shrimp in each test.

** The temperature during the treatment was $28^{\circ} \mathrm{C}$. SEMBV was injected into 10 black tiger shrimp in each test.

NT: not tested. 
Table 2. Virucidal effects of povidone-iodine on PRDV and SEMBV

\begin{tabular}{ccc}
\hline \hline $\begin{array}{c}\text { Concentration of } \\
\text { povidone-iodine* } \\
(\mathrm{ppm})\end{array}$ & \multicolumn{2}{c}{ Number of shrimp dead } \\
\cline { 2 - 3 } 100 & PRDV ** & SEMBV *** \\
50 & 0 & 0 \\
10 & 0 & 0 \\
5 & 0 & 0 \\
1 & 7 & 6 \\
0 & 8 & 8 \\
& 10 & 10 \\
\hline
\end{tabular}

* Exposure time was 30 min.

** Water temperature during the treatment was $25^{\circ} \mathrm{C}$. PRDV was injected into 10 kuruma shrimp in each test.

*** Water temperature during the treatment was $28^{\circ} \mathrm{C}$. SEMBV was injected into 10 black tiger shrimp in each test.

Table 3. Effect of heat treatment on the infectivity of PRDV to kuruma shrimp

\begin{tabular}{cc}
\hline \hline $\begin{array}{c}\text { Temperature } \\
\left({ }^{\circ} \mathrm{C}\right)\end{array}$ & Number of shrimp dead \\
\cline { 2 - 2 } & PRDV $^{*}$ \\
\hline 25 & 10 \\
40 & 10 \\
50 & 0 \\
60 & 0 \\
70 & 0 \\
80 & 0 \\
\hline
\end{tabular}

* PRDV was exposed to the temperature for $20 \mathrm{~min}$. PRDV was injected into 10 kuruma shrimp in each test.

Table 4. Effect of drying treatment on the infectivity of PRDV to kuruma shrimp

\begin{tabular}{cccc}
\hline \hline \multirow{2}{*}{$\begin{array}{c}\text { Drying time* } \\
\text { (hour) }\end{array}$} & \multirow{2}{*}{$\begin{array}{c}\text { Water content in } \\
\text { filter paper (\%) }\end{array}$} & \multicolumn{2}{c}{ Number of shrimp dead } \\
\cline { 3 - 4 } & & Dry-treatment & Control \\
\hline 0 & 86.2 & 10 & NT \\
0.5 & 3.4 & 2 & NT \\
1.0 & 3.4 & 0 & 10 \\
1.5 & 3.4 & 0 & NT \\
2.0 & 3.4 & 0 & NT \\
\hline
\end{tabular}

* The samples were placed in an oven at $30^{\circ} \mathrm{C}$, and injected into 10 kuruma shrimp in each test.

NT: not tested

\section{Tolerance to ethyl ether}

Ethyl ether-treated PRDV lost its infectivity (Table 5). Generally, a virus having an envelope loses its pathogenicity when treated with ethyl ether because of the fat-soluble envelope, and this agrees with the existence of an envelope in PRDV (Takahashi et al., 1994). BMNV was also sensitive to ethyl ether (Momoyama, 1989c).

\section{Tolerance to $\mathrm{NaCl}$}

$\mathrm{NaCl}$ concentrations of $12.5 \%$ or higher inactivated PRDV and $\mathrm{NaCl}$ concentrations of $15.0 \%$ or higher inactivated SEMBV in $24 \mathrm{~h}$ at $25^{\circ} \mathrm{C}$ (Table 6). It is clear that both viral types are sensitive to high concentrations of $\mathrm{NaCl}$.

Table 5. Effect of diethyl ether on the infectivity of PRDV to kuruma shrimp

\begin{tabular}{cc}
\hline \hline Treatment* & Number of shrimp dead \\
\hline Yes & 0 \\
No & 10 \\
\hline * Virus was treated with $20 \%$ diethyl ether in sterile sea \\
$\begin{array}{l}\text { water for } 18 \text { at } 4^{\circ} \mathrm{C} \text {, and injected into } 10 \text { kuruma shrimp } \\
\text { in each test. }\end{array}$
\end{tabular}

Table 6. Effect of $\mathrm{NaCl}$ concentration on the infectivity of PRDV and SEMBV to kuruma shrimp and black tiger shrimp, respectively

\begin{tabular}{lcc}
\hline \multirow{2}{*}{$\begin{array}{c}\text { NaCl } \\
\text { concentration* }\end{array}$ (\%) } & \multicolumn{2}{c}{ Number of shrimp dead } \\
\cline { 2 - 3 } 0.03 & PRDV** & SEMBV*** \\
\hline 0.3 & 7 & 9 \\
0.5 & $\mathrm{NT}$ & $\mathrm{NT}$ \\
1.0 & $\mathrm{NT}$ & 10 \\
3.0 & 10 & 10 \\
6.0 & 6 & 10 \\
12.5 & 0 & 7 \\
15.0 & $\mathrm{NT}$ & $\mathrm{NT}$ \\
25.0 & 0 & 0 \\
\hline$*$ The viruses were exposed to different concentrations \\
of NaCl for 24 h. \\
** The temperature during the treatment was $25^{\circ} \mathrm{C}$. \\
PRDV was injected into 10 kuruma shrimp in each \\
test.
\end{tabular}




\section{Duration of infectivity in sea water}

VP stock of PRDV maintained its infectivity in the sea water for at least 120 days at $4^{\circ} \mathrm{C}$ (Table 7). When the same preparations of virus was kept at $25^{\circ} \mathrm{C}$, the infectivity lasted more than 60 days but was lost by 120 days (Table 7). By contrast, a $10^{-7}$ dilution of the VP stock of PRDV maintained its pathogenicity for only 10 days at $4^{\circ} \mathrm{C}$ and for 7 days at $25^{\circ} \mathrm{C}$. A $10^{-7}$ dilution of the VP stock of SEMBV maintained its pathogenicity for 5 days at $28^{\circ} \mathrm{C}$ (Table 8). This result suggests that these viruses in sea water can not keep their infectivities longer than 5-7 days, and that they are easily inactivated in sea water when their concentration is low. However, at high concentration, PRDV can maintain its

Table 7. Duration of PRDV infectivity in sea water against kuruma shrimp

\begin{tabular}{ccc}
\hline \hline $\begin{array}{c}\text { Periods* } \\
\text { (days) }\end{array}$ & \multicolumn{2}{c}{ Number of shrimp dead } \\
\cline { 2 - 3 } & $4^{\circ} \mathrm{C}$ & $25^{\circ} \mathrm{C}$ \\
\hline 0 & 10 & 10 \\
5 & 10 & 10 \\
10 & 10 & 10 \\
15 & 10 & 10 \\
30 & 10 & 9 \\
60 & 10 & 6 \\
120 & 10 & 0 \\
\hline
\end{tabular}

* PRDV sea water suspensions prepared from homogenates of infected lymphoid organs were kept at $4^{\circ} \mathrm{C}$ or $25^{\circ} \mathrm{C}$, and injected into 10 shrimp after indicated periods.

Table 8. Duration of PRDV and SEMBV infectivity when suspended at lower concentrations in sea water

\begin{tabular}{cccc}
\hline \hline \multirow{2}{*}{$\begin{array}{c}\text { Period* } \\
\text { (days) }\end{array}$} & \multicolumn{3}{c}{ Number of shrimp dead } \\
\cline { 2 - 3 } & $4^{\circ} \mathrm{C}$ & $25^{\circ} \mathrm{C}$ & SEMBV*** \\
\cline { 2 - 3 } & 10 & 10 & \\
\hline 0 & 6 & 6 & 10 \\
1 & 10 & 7 & 10 \\
3 & 8 & 6 & 8 \\
5 & 10 & 4 & 2 \\
7 & 6 & 0 & 0 \\
10 & 0 & 0 & 0 \\
15 & & 0 & 0 \\
\hline
\end{tabular}

* The virus concentration used in this experiment was a $10^{-7}$ dilution of the original solution used in the previous experiment (Table 7).

** PRDV was injected into 10 kuruma shrimp.

*** SEMBV was injected into 10 black tiger shrimp. infectivity against shrimp for at least 60 days at $25^{\circ} \mathrm{C}$ or for 120 days at $4^{\circ} \mathrm{C}$.

\section{Inactivation by single oxygen $\left({ }^{1} \mathrm{O}_{2}\right)$}

In an attempt to develop a new technique to inactivate PRDV, we exposed it to singlet oxygen $\left({ }^{1} \mathrm{O}_{2}\right)$ that was generated from rose bengal upon irradiation with visible light (Gollnick, 1968; Suzuki et al., 1990). The mortality rate of the shrimp that received the ${ }^{1} \mathrm{O}_{2}$-treated virus was significantly lower than that of the control shrimp $(P<0.001)$ (Table 9), indicating that ${ }^{1} \mathrm{O}_{2}$ inactivated PRDV. Recently, application of UV light irradiation and ozonation have been developed for disinfecting sea water for aquaculture (Brown and Russo, 1979; Kobayashi et al., 1993). These techniques have been demonstrated to be effective in inactivation of fish pathogens (Sugita et al., 1992). However, the equipment for both methods is expensive in initial investment. Moreover, ozonation produces residual oxidants coupled with $\mathrm{Br}$ and $\mathrm{Cl}$ that are toxic to animals and have a long half-life. Hence, these toxic residues in sea water must be removed by activated charcoal before the sea water is transferred to aquaria (Sugita et al., 1992). On the other hand, the ${ }^{1} \mathrm{O}_{2}$ used in this study was proven to be an effective disinfectant, having a short half-life (Saito and Matsugo, 1988), and the process is simple and inexpensive. Therefore, we believe that this ${ }^{1} \mathrm{O}_{2}$ generating system has a high potential for future application at least to shrimp and fish hatcheries where they use smaller volume of water. The proportion of dye to water volume used in this experiment was rather large and the direct application of this proportion would be difficult for grow-out ponds. If we could find more efficient dye that can produce more ${ }^{1} \mathrm{O}_{2}$ with smaller

Table 9. Effect of singlet oxygen $\left({ }^{1} \mathrm{O}_{2}\right)$ on the infectivity of PRDV against kuruma shrimp

\begin{tabular}{lcc}
\hline \hline \multicolumn{1}{c}{ Treatment* } & $\begin{array}{c}{ }^{1} \mathrm{O}_{2} \\
\text { generation** }\end{array}$ & $\begin{array}{c}\text { Number of shrimp } \\
\text { (No. dead/No. tested) }\end{array}$ \\
\hline $\begin{array}{l}\text { PRDV + rose bengal + } \\
\text { visible light }\end{array}$ & Yes & $4 / 21^{\mathrm{a}}$ \\
PRDV + visible light & No & $22 / 22^{\mathrm{b}}$ \\
PRDV + rose bengal & No & $22 / 22^{\mathrm{b}}$ \\
rose bengal + visible light & Yes & $4 / 21^{\mathrm{a}}$ \\
\hline
\end{tabular}

* Treatment was done at room temperature.

** ${ }^{1} \mathrm{O}_{2}$ was generated from rose bengal by irradiation of visible light.

a, b: Significant differences between different letters $(P<$ $0.001)$. 
Table 10. Comparison of inactivation conditions between WSSV (PRDV, SEMBV) and BMNV

\begin{tabular}{lcccc}
\hline \hline \multicolumn{1}{c}{ Treatments } & $\begin{array}{c}\text { Reaction } \\
\text { conditions }\end{array}$ & PRDV* & SEMBV* & BMNV** \\
\hline Sodium hypochlorite & $10 \mathrm{~min}$ & $5 \mathrm{ppm}$ & $\mathrm{NT}$ & $5 \mathrm{ppm}$ \\
& $30 \mathrm{~min}$ & $1 \mathrm{ppm}$ & $10 \mathrm{ppm}$ & $\mathrm{NT}$ \\
Povidone-iodine & $10 \mathrm{~min}$ & $\mathrm{NT}$ & $\mathrm{NT}$ & $25 \mathrm{ppm}$ \\
& $30 \mathrm{~min}$ & $10 \mathrm{ppm}$ & $10 \mathrm{ppm}$ & $\mathrm{NT}$ \\
Heat & $50^{\circ} \mathrm{C}$ & $20 \mathrm{~min}$ & $\mathrm{NT}$ & $30 \mathrm{~min}$ \\
Drying & $30^{\circ} \mathrm{C}$ & $1.0 \mathrm{~h}$ & $\mathrm{NT}$ & $1.5 \mathrm{~h}$ \\
NaCl concentrations & $24 \mathrm{~h}$ & $12.5 \%$ & $15.0 \%$ & $12.5 \%$ \\
& $28^{\circ} \mathrm{C}$ & $\mathrm{NT}$ & 7 days & $\mathrm{NT}$ \\
Duration & $25^{\circ} \mathrm{C}$ & 10 days & $\mathrm{NT}$ & 7 days \\
& $4^{\circ} \mathrm{C}$ & 15 days & $\mathrm{NT}$ & $\mathrm{NT}$ \\
\hline NT: not tested & & & & \\
$*$ Present study & & & & \\
$*$ Momoyma $(1989 \mathrm{a}, \mathrm{b}, \mathrm{c}, \mathrm{d})$ & & &
\end{tabular}

amounts of dye, this method would become practical for aquaculture industries. We need to collect more information on the quality of the dye, the intensity of the light and the ${ }^{1} \mathrm{O}_{2}$ itself in shrimp culture ponds with heterotrophic populations of microorganisms and high concentrations of organic materials.

The present results showed that PRDV and SEMBV are sensitive to disinfectants, drying, high temperature and high concentrations of $\mathrm{NaCl}$. Table 10 summarizes the inactivation conditions for WSSV (PRDV, SEMBV) and BMNV (Momoyama, 1989a, b, c, d). As mentioned in the previous section, the comparisons among these viruses are not possible because of the inability of the quantification of these viruses. These viruses, however, were inactivated by similar conditions, even though the concentration of these viruses were not standardized. In general, shrimp ponds and instruments are tainted by organic materials originated from residual feeds, feces, and decomposed aquatic animals and plants. Therefore, the concentration of the disinfectants for practical use in shrimp farms should be higher than those mentioned in this paper because organic materials reduce the virucidal effect of these chemicals.

\section{References}

Brown, C and D. J. Russo (1979): Ultraviolet light disinfection of shellfish hatchery sea water. I. Elimination of five pathogenic bacteria. Aquaculture, 17, 17-23.
Chou, H-Y., C-Y. Huang, C-H. Wang, H-C. Chiang and C-F. Lo (1995): Pathogenicity of a baculovirus infection causing white spot syndrome in cultured penaeid shrimp in Taiwan. Dis. Aquat. Org., 23, 165-173.

Flegel, T. W. (1997): Major viral disease of the black tiger prawn (Penaeus monodon) in Thailand, In "New approaches to viral diseases of aquatic animals", NRIA International Workshop, National Research Institute of Aquaculture, Nansei, Mie, Japan, pp. 218-228.

Gollnick, K. (1968): Photooxygenation reactions in solution. In "Advances in photochemistry" (ed. by W. A. Noyes Jr et al.). John Wiley \& Sons, New York, pp. 1-122.

Huang, J., X. Song, J. Yu and C. Yang (1995): Baculoviral hypodermal and hematopoietic necrosis-study on the pathogen and pathology of the explosive epidemic disease of shrimp. Mar. Fish. Res., 16, 1-10. (In Chinese)

Inouye, K., S. Miwa, N. Oseko, H. Nakano, T. Kimura, K. Momoyama and M. Hiraoka (1994): Mass mortality of cultured kuruma shrimp Penaeus japonicus in Japan in 1993: Electron microscopic evidence of the causative virus. Fish Pathol., 29, 149-158.

Inouye, K., K. Yamano, N. Ikeda, T. Kimura, H. Nakano, K. Momoyama, J. Kobayashi and S. Miyajima (1996): The penaeid rod-shaped DNA virus (PRDV), which causes penaeid acute viremia (PAV). Fish Pathol., 31, 39-45.

Kasornchandra, J., S. Boonyaratpalin and T. Itami (1998): Detection of white spot syndrome in cultured penaeid shrimp in Asia: Microscopic observation and polymerase chain reaction. Aquaculture, 164, 243-251.

Kobayashi, T., H. Yotsumoto, T. Ozawa and H. Kawahara (1993): Closed circulatory system for mariculture using ozone. Ozone Sci. Eng., 15, 311-330.

Lo, C-F., C-H. Ho, S-E. Peng, C-H. Chen, H-C. Hsu, Y-L. Chiu, 
C-F. Chang, K-F. Liu, M-S. Su, C-H. Wang and G-H. Kou (1996): White spot syndrome baculovirus (WSBV) detected in cultured and captured shrimp, crabs and other arthropods. Dis. Aquat. Org., 27, 215-225.

Maeda, M., T. Itami, M. Kondo, O. Hennig, Y. Takahashi, I. Hirono and T. Aoki (1997): Characteristics of penaeid rodshaped DNA virus of kuruma shrimp, In "New approaches to viral diseases of aquatic animals", NRIA International Workshop, National Research Institute of Aquaculture, Nansei, Mie Japan, pp. 218-228.

Momoyama, K. and N. Sano (1988): A method of experimental infection of kuruma shrimp larvae, Penaeus japonicus Bate, with baculoviral mid-gut gland necrosis (BMN) virus. J. Fish. Dis., 11, 105-111.

Momoyama, K. (1989a): Virucidal effect of some disinfectants on baculoviral mid-gut gland necrosis $(\mathrm{BMN})$ virus. Fish Pathol., 24, 47-49.

Momoyama, K. (1989b): Inactivation of baculoviral mid-gut gland necrosis (BMN) virus by ultraviolet irradiation, sunlight exposure, heating and drying. Fish Pathol., 24, 115118.

Momoyama, K. (1989c): Tolerance of baculoviral mid-gut gland necrosis (BMN) virus to ether, $\mathrm{NaCl}$ concentration and pH. Fish Pathol., 24, 175-177.

Momoyama, K. (1989d): Survival of baculoviral mid-gut gland necrosis virus (BMNV) in infected tissues and in sea water. Fish Pathol., 24, 179-181.

Momoyama, K., M. Hiraoka, K. Inouye, T. Kimura, H. Nakano and M. Yasui (1997): Mass mortalities in the production of juvenile greasyback shrimp, Metapenaeus ensis, caused by penaeid acute viremia (PAV). Fish Pathol., 32, 51-58.

Murphy, F. A., C. M. Fauquet, D. H. L. Bishop, S. A. Ghabrial, A. W. Jarvis, G. P. Martelli, M. A. Mayo and M. D. Summers (1995): Virus taxonomy, 6th report of the international committee on taxonomy of viruses. Arch. Virol. Supplementum 10, 1-586.

Nunan, L. M. and D. V. Lightner (1997): Development of a non-radioactive gene probe by PCR for detection of white spot syndrome virus (WSSV). J. Virol. Methods, 63, 193201.

Saito, I. and S. Matsugo (1988): Chemistry of active oxygen species. Protein, Nucleic Acid and Enzyme, 33, 26652677. (In Japanese)
Sano, T., T. Nishimura, K. Oguma, K. Momoyama and N. Takeno (1981): Baculovirus infection of cultured kuruma shrimp Penaeus japonicus in Japan. Fish Pathol., 15, 185191.

Sugita, H., T. Asai, K. Hayashi, T. Mitsuya, K. Amanuma, C. Maruyama and Y. Deguchi (1992): Application of ozone disinfection to remove Enterococcus seriolicida, Pasteurella piscicida and Vibrio anguillarum from seawater. Appl. Environ. Microbiol., 46, 1157-1162.

Suzuki, N., T. Nomoto, I. Misumoto, M. Kobayashi, M. Wada, B. Wada and H. Inaba (1990): Chemiluminescence of luminol with singlet oxygen generated from a rose bengal system. Chem. Express, 5, 505-508.

Takahashi, Y., T. Itami, M. Kondo, M. Maeda, R. Fujii, S. Tomonaga, K. Supamattaya and S. Boonyaratpalin (1994): Electron microscopic evidence of bacilliform virus infection in kuruma shrimp (Penaeus japonicus). Fish Pathol., 29, 121-125.

Takahashi, Y., T. Itami, M. Maeda, N. Suzuki, J. kasornchandra, K. Supamattaya, R. Khongpradit, S. Boonyaratpalin, M. Kondo, K. Kawai, R. Kusuda, I. Hirono and T. Aoki (1996): Polymerase chain reaction (PCR) amplification of bacilliform virus (RV-PJ) DNA in Penaeus japonicus Bate and systemic ectodermal and mesodermal baculovirus (SEMBV) DNA in Penaeus monodon Fabricius. J. Fish. Dis., 19, 399-403.

Wang, C-H., C-F. Lo, J-H. Leu, C-M. Chou, P-Y. Yeh, H-Y. Chou, M-C. Tung, C -F. Chang, M-S. Su and G-H. Kou (1995): Purification and genomic analysis of baculovirus associated with white spot syndrome (WSBV) of Penaeus monodon. Dis. Aquat. Org., 23, 239-242.

Wang, C-S., Y-J. Tsai, G-H. Kou and S-N. Chen (1997): Detection of white spot disease virus infection in wild-caught greasy back shirmp, Metapenaeus ensis (de Haan) in Taiwan. Fish Pathol., 32, 35-41.

Wongteerasupaya, C., J. E. Vickers, S. Sriurairatana, G. L. Nash, A. Akarajamorn, V. Boonsaeng, S. Panyim, A. Tassanakajon, B. Withyachumnarnkul and T. W. Flegel (1995a): A non-occluded, systemic baculovirus that occurs in cells of ectodermal and mesodermal origin and causes high mortality in the black tiger prawn Penaeus monodon. Dis. Aquat. Org., 21, 69-77. 